\title{
The University Teacher's Competence in the Process of the Paradigmatic Shift
}

\section{Introduction}

When thinking of the competence of graduates entering the labour market today, one takes into account not only their knowledge and specialist skills connected with their field of study. In the last decades, special emphasis has been put on social competence, necessary for building interpersonal relations and teamwork. The competence required from university graduates also includes cognitive skills, which are of a universal character, independent from the syllabus and content of academic classes. Nowadays it is expected students to have the skill of reflective and critical thinking, the ability to seek relations among different issues, to understand and explain them, to provide arguments and discuss them. In other words, we - as the society - want the young generation to ultimately understand the ongoing processes and be aware of the mechanisms applied in different areas of our socio-economic and cultural functioning. However, it takes a long time to shape such competence and it should be done at classes, in which the teacher allots time and space for initiating the abovementioned cognitive activities. By designing teaching situations which give an opportunity to explore cognitively, we help students to develop the deep approach to learning (Biggs, Tang, 2007). Contrary to the surface approach to learning, it is not confined to remembering, identifying, naming and, if necessary, paraphrasing content, but is based on an in-depth study of facts and ideas in an active and critical way. In the learning process, students have a chance of utilizing their prior knowledge and, owing to

(1) https://orcid.org/0000-0001-5670-9754 
being involved in the process, they are able to extend and reconstruct their cognitive structures. Thus, they create knowledge that is relevant to them and is applicable in different contexts. Such an approach is characteristic of non-objectivist educational paradigms, in which knowledge is of an individual and subjective nature and is the product of the multilateral involvement in the learner's process. What is the key factor that plays a role in developing and reinforcing students' deep approach to learning is academic staff's proper teaching competence, especially "teaching and assessment methods, which support active and long-term involvement in learning situations" (Ramsden, 2002).

In this chapter, the focus is put on teaching competence of academic lecturers that emphasizes their utmost importance for students' learning, for developing their approach to the teaching process and the educational effects they obtain. The goal is to reconstruct this issue, taking into consideration changes that are happening in academic teaching. The paradigmatic shift towards student-centred education, which is clearly accentuated in the literature, must be reflected in university teachers' actions. Therefore, in the first part of the chapter, the trend of educational transformation is shortly discussed, explaining that it generally concerns moving from objectivist to non-objectivist paradigms, while specifically it refers to a change from teaching based on behaviourist theses to constructivist education. Thus, in the next section, the theses of didactics inspired by the premises of educational constructivism are presented, and the model of constructivist classes is also discussed. The given assumptions and guidelines for teaching design show the necessity of developing and modifying competence that the constructivist teacher needs. Thus, academics' pedagogical competence is described, providing an overview of aspects which constitute the new understanding of it. In this way, the process which requires lecturers to undertake individual effort and change is shown. The process that requires change not only their actions, but, even more importantly, their beliefs regarding knowledge and learning. At the same time, it is emphasized that the transformation needed today should be a job performed by different stakeholders, the effort made by various parties: the academics, but also the university as the organisation that employs them. In the process of change, the lecturer needs constant and comprehensive support.

\section{From passing knowledge to the facilitation of learning}

In today's academic teaching, we observe the paradigmatic change consisting in the shift from teaching to supporting learning (Dylak, 2009; Kember, 2009; Malewski, 2010; Wach, 2019; Wright, 2011), which is particularly emphasized in Anglo-Saxon textbooks in the field of the scholarship of teaching and learning (Biggs \& Tang, 2007; Fry et al., 2009; Ramsden, 2002). It is proposed that "passing on knowledge should be replaced by teaching cognitive and existential self-reliance" (Kwiatkowska, 2008, p. 41), and that the educational culture of imposing should give way to the culture of offering. This need was stressed in 
the frequently quoted article included in the Change journal (Fear et al., 2003), entitled The Shift from Teaching to Learning (Barr, Tagg, 1995). Its authors not only presented the vision of the paradigmatic shift, but they also used the characteristic expression "learning paradigm" (Fear et al., 2003). As they suggested, modern education favours orientation with the student placed in the centre of the educational process, called "the facilitation of learning", which is replacing teacher-and-content-centred education, based on "passing knowledge" (Kember, 2009; Kember, Gow, 1994; Samuelowicz, Bain, 2001). In other words, in thinking about the student and the educational process, approaches based on the behaviourist paradigm give way to the humanist, constructivist and critical-emancipatory paradigm. Thus, objectivist paradigms are being abandoned in favour of non-objectivist ones, which share the same epistemological and ontological approach. Although there has been a lot of discussion recently about the multi-paradigmatism and the co-occurrence of various perspectives in theory and practice, resulting in the creation of eclectic approaches which eliminate the efficiencies of each of them (Klus-Stańska, 2018), it is educational constructivism that is the most frequently quoted theoretical approach in the literature on the subject. As opposed to behaviourist theses, some propose constructivist ones (instruction, passing knowledge vs. construction, building knowledge) (Carnell, 2007). Constructivist teaching, which places the student in the centre, is an alternative to conventional methods with the teacher on the podium (Yuen, Hau, 2006). Smit, de Brabander \& Martens (2014) point out that student-centred education is "based on those learning theories that consider learning as a constructivist, situated and social activity" (p. 696), in which it is students rather than teachers that take responsibility for the process. By comparing the two learning environments, the authors clearly refer to the premises of constructivism and behaviourism. In the same context, the relation of constructivism with the student-centred approach has also been observed by Elen et al., (2007). The two-paradigm approach, with the model based on the tenets of positivist and constuctivist teaching, is presented by Gage (2009). The paradigmatic shift from teaching to learning, defined as moving towards the constructivist approach in teaching, was mainly stressed by the abovementioned Barr \& Tagg (1995), who believe that "a collage's purpose is not to transfer knowledge but to create environments and experiences that bring students to discover and construct knowledge for themselves, to make students members of communities of learners that make discoveries and solve problems" (p. 15). Thus, they clearly indicate the shift towards constructivist theses in the scholarship of teaching and learning.

The above assumptions and the analysis of the academic teaching process from different theoretical perspectives (Wach, 2019) let us state that educational constructivism is probably the most common "learning" paradigm, and, given the organizational conditions of the teaching process, including system and organization elements, it also seems to be the most applicable one, counterpoising the behaviourism-based approach, which is so strongly rooted at universities. What is the strength of constructivism is not only the central position of the student, but also the fact that the constructivist tenets concerning cognition and 
learning have led to the formulation of teaching rules, constituting a cohesive model that could be applied at all levels of education, including university teaching (Biggs, Tang, 2007).

\section{The assumptions of constructivist theory}

The constructivist paradigm is now the most intensively developed approach to teaching. It seems to be the most common theoretical approach of all (Golębniak, 2002; Klus-Stańska, 2018; Sajdak, 2013). It is an internally strongly diverse approach, which is constantly evolving (Dylak, 2000; Gołębniak, 2005; Klus-Stańska, 2010, 2018; Rutkowiak, 2009; Sajdak, 2013). This diversity is the reason for which, despite the current fashion, the tenets of constructivist teaching are not always properly interpreted (Klus-Stańska, 2010). To understand the main ideas of this approach, one should refer to the views of Piaget (cognitive constructivism), Vygotsky (social constructivism), and Bruner, who, just like, Vygotsky, emphasized the socio-cultural aspects of the constructivist perspective (Wach, 2019).

When referring to the philosophical foundations of constructivism, one should point out that, as a non-objectivist paradigm, "it advocates the world which is built, perceived and interpreted by the man in a subjective way" (Sajdak, 2013, p. 390). The reality in which an individual functions is not an independent being, but is the result of human cognition, a kind of the construction of the world. Similar assumptions refer to knowledge, which is not an external phenomenon, "a set of information", but a subjective category that is individually constructed and reconstructed in the process of human cognition, and is embedded and interpreted in a specific cultural context (Klus-Stańska, 2010). As Dylak indicates (2000) "knowledge is not beyond us and it is not waiting to be discovered (...); the reality is not separated from the observer; it is some unity; it is the observers who create the meaning of what they see and, thus, the knowledge of what they see and the world in which they live" (pp. 65-66).

Constructivism is also embedded in the cognitive psychological concept of the man, according to which people are independent, creative and intellectually stimulated individuals, who are interested in the world and are guided by curiosity in the process of exploring the reality (Łukaszewski, Doliński, 2000; Sajdak, 2013). They ask questions and experience cognitive dissonance (a conflict, incompatibility between previous knowledge, concepts and experiences and new, incoming stimuli), and, in their thinking and actions, aim to find answers to the questions that are bothering them. These people learn by processing information coming from outside, and giving it meaning themselves (Ledzińska, Czerniawska, 2011), but also by using their previous knowledge resources, gathered in so-called cognitive structures (Kozielecki, 1995). The interaction that occurs in the mental representations of the world (through Piaget's mechanisms, such as assimilation and accommodation) supports the 
process of learning and creating individual knowledge, which is meaningful for a particular person (Illeris, 2006). This knowledge is negotiated in the social context, among other people learning and organizing the learning environment. It takes place in the zone of proximal development (Vygotski, 1978), in the peer group and in the presence of the teacher-facilitator and in the process of building the scaffolding. The learner gradually takes control and responsibility (Dylak, 2013; Filipiak, 2012, 2018; Ledzińska, Czerniawska, 2011; Pritchard, 2009), gaining space and time for the autonomous construction of his or her knowledge. Learning in accordance with the tenets of constructivism also takes place in the cultural context, which was particularly emphasized by Bruner (2006). He argued, in line with Vygotsky's views, that in order to give and interpret meanings, one should have the knowledge of culture and cultural tools (in the specific language), because culture is a source and medium which shapes the human mind, and helps it function and develop (Filipiak, 2012; Gergen, 1995; Sajdak, 2013).

Constructivism is a theory of knowledge and cognition, in which learning and learners occupy the focal position. Dylak proposes a neat and accurate definition of learning from this point of view (2000). Quoting the works of Lloyd (1995) and Lewis (1996), he points out that "learning (...) is a self-regulatory process of tackling a conflict between the existing, personal models of the world and the information coming from outside (...) it is a process of building new models and representations of the world with the use of cultural tools and symbols; it is a process of constantly negotiating meanings, through learning, teamwork and discourse" (p. 66). Thus, what are the implications of the constructivist assumptions for the teaching process? Although constructivism "describes and explains the universal essence of the processes of cognition and learning" (Klus-Stańska, 2018, p. 136), this does not mean that its main theses cannot be used to formulate guidelines for designing and teaching classes, "identifying what teaching methods give a chance for better education" (Klus-Stańska, 2018, p. 136). The constructivist principles concerning learning may serve as a kind of framework for teachers and educators, determining the teaching methodology (Biggs, Tang, 2007; Fosnot, Perry, 2005; Klus-Stańska, 2010). The analysis of a number of publications (Biggs, Tang, 2007; Filipiak, 2012; Fosnot, Perry, 2005; Fry et al., 2009; Klus-Stańska, 2012, 2018; Ledzińska, Czerniawska, 2011; Pritchard, 2009; Sajdak, 2013) led to adopt the principles of constructivist teaching as proposed by Klus-Stańska (2010), but they were supplemented with the views of other theoreticians of teaching, and they were embed in the context or academic teaching:

- The student's activity as the starting point. Learners' involvement helps them handle, though often inefficiently, the cognitive situation designed by the teacher (Klus-Stańska, 2010). The teacher's task at the initial stage of the teaching process is to arrange so-called learning opportunities and activate students' prior knowledge. Such a solution is proposed instead of the so-called typical "introduction to the subject". The constructivist-teacher is a designer and moderator of teaching situations rather than a transmitter of knowledge. 
- Problem situations as key to stimulating the student's interest, triggering the cognitive conflict and arousing internal motivation (Klus-Stańska, 2010). The proposed task should be a challenge, should give rise to controversy and encourage posing hypotheses and taking verifying actions (Fosnot, Perry, 2005). Teaching based on inquiring and seeking solutions also finds application during lectures, which is confirmed by the current popularity of interactive teaching in large classes (Morton, 2009).

- The student's prior knowledge, i.e. his or her previous experience and knowledge, as having importance for the learning process (Klus-Stańska, 2010). The activation of prior knowledge supports building cognitive structures and combining new portions of information with the existing resources. Diagnosis is particularly important as it allows the teacher to design cognitive tasks that go beyond the zone of proximal development. In other words, "teachers have to understand where the learners are so that they (the students) can obtain the proper level and adjust misconceived notions and fill in their own competence gaps" (Fry et al., 2009, p. 22). By creating opportunities to share resources and experiences, we make learning more contextual and based on sharing and cooperating, and we support the process of negotiating the reality.

- Recognizing what the student means rather than guessing what the teacher thinks (Klus-Stańska, 2010). In the constructivist educational process, it is essential to ask questions and discover students' thinking models, their notions, understanding and perception of the reality. The teacher encourages learners to formulate rules independently, discover them and defend their own position (Brzezińska, 2006; Fosnot, Perry, 2005). Thus, he or she supports the process of developing intellectual competence, such as analytical, reflective and critical thinking.

- The social negotiation of understanding the reality in the learning process instead of assimilating someone else's concepts (Klus-Stańska, 2010). Creating opportunities to exchange, discuss and view the reality from different perspectives, which supports the in-depth and more thorough understanding of the issue under study (Fry et al., 2009).

- The cognitive procedures of achieving the result in the student's memory rather than only the effects of his or her mental activity (Klus-Stańska, 2010). In the constructivist approach, the process of gaining knowledge is more important than the end result in the form of specific knowledge. Thus, the teacher's task is to create the space in which students will have an opportunity to explore and find their own way of action and methods of solving problems before the so-called "explanatory and conceptual activity of the teacher" follows (Klus-Stańska, 2010, p. 332). It is important to give them a chance to pose hypotheses, ask questions, order information in accordance with their own criteria, compare facts, and create associations and metaphors. These processes support in-depth, permanent and holistic learning, and contribute to the development of cognitive competence, which the man uses at every stage of life-long education. 
- Learning on the unconscious level as a significant part of the process of obtaining knowledge (Klus-Stańska, 2010). This means that even students themselves not always notice an educational change, particularly in the area of cognitive or social competence. Only some teaching outcomes can be observed and measured with the application of quantitative tools and that is why constructivists recommend qualitative approaches and techniques of formative assessment, such as portfolio, essay, open questions (Angelo \& Cross, 1993).

- Mistakes made by students as a natural element of learning (Klus-Stańska, 2010). They should be perceived as the result of students' reasoning (creating the concept of the reality) and, thus, they should not be reduced or prevented (Fosnot, Perry, 2005); just the opposite - we should take interest in the students' way of thinking and help them get through the accommodation process, without stigmatizing, evaluating or rebuking, but we should see the "misconceived" (i.e. different) interpretation of the reality as an intellectual fact and the starting point for negotiating meanings.

- Learning opportunities as an element of educational planning, with no possibility of precisely formulating the teaching outcomes (Klus-Stańska, 2010). Teaching is about "the creation of the learning environment and offering problem situations" (Klus-Stańska, 2010, p. 341), which will be filled with meanings by students themselves. The teacher may only outline the area of cognitive activity, but he or she cannot precisely formulate the goals of teaching, which will be dependent on the involvement and action of learners and the relations they will establish. The teacher's task is thus to follow the students and be flexible depending on their interests and other needs.

The above assumptions do not constitute the complete list of principles and rules important from the point of view of designing and teaching classes inspired by the ideas of constructivism. They are the framework for creating the class model with the learner's multiple activities at its heart. An overview of the literature shows that the model of constructivist classes consists of a few stages (Gołębniak et al., 2002; Klus-Stańska, 2010; Michalak, 2004; Sajdak, 2013; Wynne, 1996). The presented approaches differ - each of the proposals encompasses the issue of planning and teaching classes on a different level of detail, although all of them can serve as valuable guidelines for constructivist teachers. For example, Klus-Stańska's constructivist teaching model (2010) consists of the following stages: "cognitive conflict exploration and personal procedures of understanding social negotiation change and functioning of meanings in the mind" (p. 352). Sajdak (2013), in turn, focuses on the structure elements of the teaching process, beginning from formulating goals, diagnosing prior knowledge through creating learning opportunities, to measuring students' achievements and evaluating classes. Gołębniak et al., (2002) address the issue of planning on a few levels, but we should definitely mention the stages of classes in the design method they described: involvement search transformation presentation reflection. Wynne (1996) indicates the following stages of planning constructivist classes: identifying and revealing knowledge constructing and restructuring new 
knowledge referring the modified theories applying new knowledge. Michalak (2004) comes up with a similar proposal for early school education. Following this path, the stages embedded in the context of academic education are presented below:

1. The identification and recognition of knowledge, in which cognitive curiosity is stimulated, interest in the topic is aroused, students' prior knowledge is diagnosed, and the teacher poses the problem task.

2. Revealing learners' preliminary concepts, ideas and experiences, which help to activate the previous structures of knowledge. Students become aware of what they do not know, the teacher finds out what their level of competence is, what experiences they have had and how they interpret them, and what ideas for solving a specific problem they have, and whether and what mistakes they make. The teacher adapts teaching methods and the difficulty level to his or her students' capacity and interests.

3. The restructuring of knowledge is the phase in which students absorb new information in the process of assimilation or accommodation and reconstruct their own knowledge, expanding or rebuilding their cognitive formats.

4. The ability to use new knowledge in different situations comes in the application phase, i.e. companioning theory with practice and the application of knowledge and skills in new contexts.

5. The review of changes in students' knowledge as they become aware of the change that has occurred in their structures of knowledge. The teacher supports their self-evaluation, stimulates the process of reflection and analysis of activities undertaken by students, and uses the techniques of formative assessment.

The use of the constructivist model of teaching in academic education requires teachers to change their perspective of what knowledge is, what learning consists in, and in what conditions it occurs, so that they could later develop their competence in the sphere of planning, organizing and supporting students' learning. The teacher who is going to work in the constructivist paradigm has to abandon the behaviourism-based transmission model, which is strongly rooted at university, and redefine his or her role: from an "omniscient" expert - the transmitter of knowledge - to the designer of learning situations and the facilitator of the educational process, giving the central position to his or her students.

The growing body of the research is seen as the support for such theoretical assumptions. Especially the learning context and student-centred/teacher-based environment are meaningful for supporting student learning, shaping his/her approach to learning: deep or surface (Baeten et al., 2010; Baeten et al., 2013; Lindblom-Ylänne, Lonka, 2000; Prosser, Trigwell, 1999; Vermunt, 1995). The other important group of research shows the relations between the academics' perception and understanding of such processes as learning and teaching, the teaching methods they use in the classroom and the way how it influences on students' approach to learning (deep and surface) and learning outcomes (Kember, Kwan, 2000; Trigwell et al., 1999). 


\section{Teaching competence from the constructivist perspective}

The paradigmatic shift, which moves the focus to the student's learning and involvement, requires totally different teaching competence than in the transmission model. Strong technical and instrumental approach to teaching, typical of the previous behaviourist paradigm (Kwaśnica, 1994, 2006), have given way to the philosophy of reflective practice (Gołębniak, 1998), with consideration "in action" and "on action". Competence from the constructivist point of view does not come down to a trade defined as reproducing algorithmic sets of actions used in "teaching" students, but is a category that is dynamically created, extended and developed under the influence of new teaching situations which the teacher finds himor herself. It is thus and incomplete category, which is constantly "on the move" and which requires openness to the new and readiness to become modified.

The paradigmatic transformation and the shift from transferring content to the support of learning requires not only a change of attitude towards one's competence and teacher's development, but also a change in the perception of knowledge, of what learning is and what teaching should consist in. It is an extremely challenging task, considering the fact that the traditional teaching models at university are based on the transmission model, which originates from positivist pedagogy. Hence, the proposed change consists in moving from the role of an omniscient expert to the position of the facilitator - who diagnoses the student's development potential, organizes a rich learning environment, creates educational opportunities, supports students in the process of building knowledge and values their autonomy and freedom of choice, promoting shared responsibility for the educational process (Filipiak, 2012; Fosnot, Perry, 2005; Fry et al., 2009; Klus-Stańska, 2010). Once acquired skills are not sufficient, but need modifications depending on the educational situations in which teachers find themselves. They require that teachers are sensitive to students' needs and are ready to learn for their whole life.

The above approach is reflected in the model proposed by Apelgren \& Giertz (2010), who view pedagogical competence (defined as teaching competence) as "the ability and will to regularly apply to attitude, the knowledge, and the skills that promote the learning of the teacher's students in the best way. This shall be in agreement with the goals that apply, and within the framework available and presupposes continuous development of the teacher's own competence and instructional design" (p. 30). In their publication, they specify their own understanding of this notion and, what is more, they propose the evaluation criteria of teaching competence (Apelgren, Giertz, 2010; Wach, 2019): (1) an attitude that promotes learning (2) based on research and a scholarly attitude, (3) broad and current knowledge of the subject, (4) knowledge about how students learn, (5) knowledge about teaching, (6), awareness of goals and frameworks, (7) holistic view, (8) applied teaching skills (9) striving for continuous improvement, (10) leadership and organisational ability, (11) collaboration with others and external contacts.

An attitude that furthers student learning is an approach which assumes the positive motivation of students and the subjective treatment of them in the 
educational process. The teacher defines his or her role and the tasks for students, as well as specifying the responsibilities of both sides. He or she does it in a friendly, open atmosphere of dialogue, informing students about the causes of and motives behind his or her actions. The teacher includes students in the educational process, negotiating the teaching goals, taking into account their prior knowledge, experience, interests and the possibility of getting engaged in the process.

Another aspect taken into account when it comes to understanding teaching competence is the research-based and scholarly attitude, also referred to as the scholarship of teaching and learning in the Anglo-Saxon literature. It includes the latest research findings concerning academic teaching in the educational process and takes into consideration the results of studies conducted in the field of the subject taught. This approach is also defined as the reflective and critical attitude, and, first of all, as supporting students in the development of deep and critical thinking in the evaluation of scientific phenomena.

The third of the factors is broad and appropriate subject knowledge, which is related to expert knowledge. This knowledge is updated, broad and consistent with the most recent research findings in a given discipline. While this aspect seems to be natural, because the academic lecturer's competence has always been based on specialist knowledge and substantive preparation for classes, the following aspects are not so obvious or are not given much weight in practice. One of them is knowledge about how students learn and knowledge about teaching. One must admit that so far the issues regarding learning mechanisms have seldom been the subject of interest of university teachers - who have not got any diploma in education. In the new approach, it is important for the teacher to have knowledge of the learning process, to know and consider various learning styles and students' individual qualities while planning classes, and to translate this knowledge into classroom methodology. This issue is strictly connected with another aspect, i.e. knowledge about teaching. This link is particularly significant as the methodology of work, the applied strategies and techniques of teaching and assessment should stem from the teacher's knowledge of the learning process and his or her views on it. It is essential that they be paradigmatically cohesive. The academic teacher should have knowledge and skills regarding different applicable teaching approaches and methods. He or she should also know techniques of formative assessment and be able to use the constructivist class model.

Another aspect of the evaluation of teaching competence as proposed by Apelgren \& Giertz (2010) is knowledge about educational goals and the organization. This criterion refers to the awareness of the general goals of the scholarship of teaching and learning and the regulations concerning higher education. The teacher is able to prepare a class syllabus by following curriculum guidelines and teaching outcomes. Moreover, the syllabus also takes into consideration the labour market needs, supporting the student in vocational training. The goals and organizational framework of classes is discussed, which helps the student to 
comprehend the essence of the educational process. The contemporary teacher is also required to have a holistic view of the whole curriculum. The teacher should not only be knowledgeable about the subject he or she teaches, but, during classes, should also refer to the content taught by other lecturers, supporting the student in integrating and supplementing knowledge, making it complete and permanent. In other words, it is essential that the teacher help the student in establishing links between various subjects, so that they would be better understood and applied in practice.

What is another important aspect of pedagogical competence are applied teaching skills, which focus on the practical aspect of teaching capabilities. They stress the ability to use different educational strategies, methods and techniques depending on teaching goals and students' needs, including their individual characteristics. Teachers are required to structure the content of teaching in order to support processes of assimilation and accommodation in the cognition process. They can also use formative assessment and apply diverse evaluation techniques, both of the qualitative and quantitative character. In their work, teachers spend a lot of time preparing materials for students, including academic textbooks. Their classes are highly appraised, and their students get very good marks at examinations.

According to Kwaśnica $(1994,2006)$, the academic teacher's competence from the constructivist perspective is never ready, sufficient or complete. Therefore, striving for continuous improvement has become part of the lecturer's development at every stage of his or her professional career. The teacher is a reflective practitioner in action (Schön, 1987), who constantly analyses his or her teaching skills in a deep and critical manner. It is the teacher who takes into consideration evaluation conclusions, who hones his or her skills and discusses the applied teaching methods and assessment techniques with other teachers. He or she participates in workshops and conferences on teaching in higher education institutions, sharing his or her experiences with fellow teachers. The university lecturer also publishes texts about teaching. In other words, such a teacher works for the development of the discipline he or she specializes in, but also contributes to the development of the scholarship of teaching and learning.

The last two aspects of teaching competence are interrelated to a certain extent. Leadership and organizational ability, as well as collaboration with others and external contacts refer to interpersonal relations. Considering the fact that the work of academic teachers is of a highly individual character as they usually prepare for classes, draw up methodological plans and give lectures or teach classes on their own, social interaction and co-learning are of importance from the constructivist point of view. Thus, teachers should cooperate with each other and should gather around leaders, who stimulate development and encourage others to share their experiences. By submitting various ideas and solutions for validation, being open to constructive criticism and drawing on the experience of others, teachers build the communities of practitioners, eliminating the sense of loneliness and warding of threats related to professional burnout. 


\section{Final conclusions}

The above description of teaching competence from the angle of educational constructivism shows how much work a lot of teachers have to undertake in the process of the transformation of their role. It is not only a technological and instrumental effort connected with the methodology of the educational process, but also, more importantly, a mental change referring to the definition of notions such as: knowledge, learning and teaching. It is quite a strenuous job since it requires "separating oneself" from traditional, well-established patterns of transmission teaching present at universities for centuries. To complete this task, academics need to modify their thinking of their role as a teacher, abandon their ex cathedra position in favour of a partner relation, and support students in the learning process. The teacher is no longer an infallible expert, who presents the teaching material and verifies the degree to which it has been memorized, but becomes a person who joins his or her students in their individual process of building knowledge. His or her task to a large extent consists in organizing the learning environment, providing necessary materials and tools, and fulfilling advisory and supportive functions (Klus-Stańska, 2018). The teacher becomes a creative designer and facilitator of students' activity, who flexibly responds to their needs and incessantly reflects "in action" and "on action", which in practice translates into the so-called deep approach to learning discussed in the first part of this chapter. As students interact with such a teacher and are taught in the manner inspired by constructivist ideas, they become active, creative, independent people, who are curious about the world, have highly developed cognitive skills, have an unwavering belief in themselves, and see "themselves as the source of own actions, goals as the subject of their intentions and the world around them as a chance to fulfil their potential" (Sajdak, 2013, p. 417).

To conclude, it must be pointed out that the paradigmatic shift that we discussed - from teaching to the facilitation of learning - requires not only an individual effort on the part of the academic lecturer. The teacher must not be and should not be left alone on "the battlefield". This process should involve the whole community of the university, including its authorities, which set trends concerning the improvement of the quality of teaching, but also ensure the system of support. In the process of the development of the teacher's pedagogical skills, offering help rather than controlling development should be promoted (Kwaśnica, 2006; Sajdak-Burska, 2018), so it is important to create proper growth conditions at university through moulding the organizational learning culture and promoting the quality of teaching. It is thus essential that such a permanent and comprehensive system of teacher's development support be built. With this respect, the university may undertake activities which are part of its offer of educational programmes: inductive courses, followed by specialist courses aimed at the development of specific skills, methodological counselling, supportive class observations, coaching and mentoring schemes, and granting awards for the development of teaching competence. It is also necessary to promote good educational practice, organize teaching conferences, methodological seminars 
etc. Grassroots initiatives, establishing practitioners' communities or informal discussions should also be encouraged. What is another group of pro-quality activities are initiatives launched from the level of organizational units, in which teachers should have a chance to develop their teaching competence on a daily basis, during meetings concerning the issues of teaching, at peer observations or taking part in classes taught by teams of teachers (Wach, 2019). These and other similar activities can support teachers in the process of transformation, in the development of teaching competence embedded in the constructivist perspective.

\section{References}

Angelo, T. A., \& Cross, K. P. (1993). Classroom Assessment Techniques: a Handbook for College Teachers. San Francisco: Jossey-Bass Publishers.

Apelgren, K., \& Giertz, B. (2010). Pedagogical Competence - A Key to Pedagogical Development and Quality in Higher Eduaction. In Å. Ryegård, K. Apelgren \& T. Olsson (Eds.), A Swedish Perspective on Pedagogical Competence (pp. 25-40). Uppsala: Uppsala University, Division for Development of Teaching and Learning.

Baeten, M., Kyndt, E., Struyven, K., \& Dochy, F. (2010). Using Student-Centred Learning Environments to Stimulate Deep Approaches to Learning: Factors Encouraging or Discouraging Their Effectiveness. Educational Research Review, 5(3), 243-260. https:// doi.org/10.1016/j.edurev.2010.06.001

Baeten, M., Struyven, K., \& Dochy, F. (2013). Student-Centred Teaching Methods: Can they Optimise Students' Approaches to Learning in Professional Higher Education? Studies in Educational Evaluation, 39(1), 14-22. https://doi.org/10.1016/j.stueduc.2012.11.001

Barr, R. B., \& Tagg, J. (1995). From Teaching to Learning - A New Paradigm for Undergraduate Education. Change: The Magazine of Higher Learning, 27(6), 12-26. https://doi. org/10.1080/00091383.1995.10544672

Biggs, J., \& Tang, C. (2007). Teaching for Quality Learning at University. McGraw Hill, Berkshire: Society for Research into Higher Education \& Open University Press.

Bruner, J. (2006). Kultura edukacji [The Culture of Education]. Kraków: Universitas.

Brzezińska, A. (2006). Wstęp [Introducation]. In J. Bruner (Ed.), Kultura edukacji [The Culture of Education]. Kraków: Universitas.

Carnell, E. (2007). Conceptions of Effective Teaching in Higher Education: Extending the Boundaries. Teaching in Higher Education, 12(1), 25-40. https://doi. org/10.1080/13562510601102081

Dylak, S. (2000). Konstruktywizm jako obiecująca perspektywa kształcenia nauczycieli [Constructivism as a Promising Perspective for Teacher Education]. In H. Kwiatkowska, T. Lewowicki \& S. Dylak (Eds.), Wspótczesność a kształcenie nauczycieli [Contemporary Times and Teacher Education] (pp. 63-82). Warszawa: Wyższa Szkoła Pedagogiczna ZNP.

Dylak, S. (2009). Koniec "nauczania" czy nowy paradygmat dydaktyczny [The End of “Teaching” or a New Didactic Paradigm]. In L. Hurło, D. Klus-Stańska \& M. Łojko (Eds.), Paradygmaty wspótczesnej dydaktyki [Paradigms of Modern Didactics] (pp. 40-49). Kraków: Oficyna Wydawnicza "Impuls". 
Dylak, S. (2013). Architektura wiedzy w szkole [Knowledge Architecture at School]. Warszawa: Difin.

Elen, J., Clarebout, G., Léonard, R., \& Lowyck, J. (2007). Student-Centred and Teacher-Centred Learning Environments: What Students Think. Teaching in Higher Education, 12(1), 105-117. https://doi.org/10.1080/13562510601102339

Fear, F. A., Doberneck, D. M., Robinson, C. F., Fear, K. L., Barr, R. B., Van Den Berg, H., ... Petrulis, R. (2003). Meaning Making and "The Learning Paradigm": A Provocative Idea in Practice. Innovative Higher Education, 27(3), 151-168. https://doi. org/10.1023/a:1022351126015

Filipiak, E. (2012). Rozwijanie zdolności uczenia się. Z Wygotskim i Brunerem w tle [Developing Learning Abilities. With Vygotsky and Bruner in the Background]. Sopot: Gdańskie Wydawnictwo Psychologiczne.

Filipiak, E. (2018). Budowanie rusztowania dla myślenia i uczenia się dzieci w perspektywie społeczno-kulturowej teorii Lwa S. Wygotskiego [Building Scaffolding for Children's Thinking and Learning in the Perspective of the Socio-cultural Theory of Lev S. Vygotski]. In K. Przyszczypkowski, S. Futyma \& G. Barabasz (Eds.), Edukacja a myślenie. Inkluzja czy wspótmierność... [Education and Thinking. Inclusion or Proportionality...] (pp. 175-197). Poznań: Wydawnictwo Naukowe UAM.

Fosnot, C. T., \& Perry, R. S. (2005). Constructivism: A Psychological Theory of Learning. In C. T. Fosnot (Ed.), Constructivism. Theory, Perspectives, and Practice (pp. 8-38). New York, London: Teachers College Press.

Fry, H., Ketteridge, S., \& Marshall, S. (2009). A Handbook for Teaching and Learning in Higher Education: Enhancing Academic Practice. New York, London: Taylor \& Francis.

Gage, L. N. (2009). A Conception of Teaching. New York: Springer Science \& Business Media.

Gergen, K. J. (1995). Social Construction and the Educational Process. In L. P. Steffe \& J. Gale (Eds.), Constructivism in Education (pp. 17-39). New Jersey: Lawrence Erlbaum Associates.

Gołębniak, B. D. (1998). Zmiany edukacji nauczycieli. Wiedza-biegłość-refleksyjność [Changes in Teacher Education. Knowledge-Proficiency-Reflectiveness]. Toruń-Poznań: Wydawnictwo Edytor.

Gołębniak, B. D. (2002). Nabywanie kompetencji do refleksyjnego nauczania [Acquiring Competences for Reflective Teaching]. In B. D. Gołębniak (Ed.), Uczenie metoda projektów [Learning by Project Method]. Warszawa: Wydawnictwa Szkolne i Pedagogiczne.

Gołębniak, B. D. (2005). Konstruktywizm - moda, "nowa religia" czy tylko/aż interesująca perspektywa poznawcza i dydaktyczna? [Constructivism - fashion, "new religion" or just an interesting cognitive and didactic perspective?]. Problemy Wczesnej Edukacji, 1(1), 13-20.

Gołębniak, B. D., Potyrała, D., \& Zamorska, B. (2002). Ważne decyzje i działania. Przewodnik "projektowania" [Important decisions and actions. Design Guide]. In B. D. Gołębniak (Ed.), Uczenie metoda projektów [Learning by Project Method]. Warszawa: Wydawnictwa Szkolne i Pedagogiczne.

Illeris, K. (2006). Trzy wymiary uczenia się: poznawcze, emocjonalne i społeczne ramy wspótczesnej teorii uczenia sie [Three Dimensions of Learning: Contemporary Learning Theory in the Tension Field Between the Cognitive, the Emotional and the Social]. Wrocław: Wydawnictwo Naukowe Dolnośląskiej Szkoły Wyższej Edukacji TWP.

Kember, D. (2009). Promoting Student-Centred Forms of Learning Across an Entire University. Higher Education, 58(1), 1-13. https://doi.org/10.1007/s10734-008-9177-6 
Kember, D., \& Gow, L. (1994). Orientations to Teaching and Their Effect on the Quality of Student Learning. The Journal of Higher Education, 65(1), 58-74. https://doi. org/10.2307/2943877

Kember, D., \& Kwan, K.-P. (2000). Lecturers' Approaches to Teaching and Their Relationship to Conceptions of Good Teaching. Instructional Science, 28(5), 469-490. https:// doi.org/10.1023/A:1026569608656

Klus-Stańska, D. (2010). Dydaktyka wobec chaosu pojęć i zdarzeń [Didactics in the Face of Chaos of Concepts and Events]. Warszawa: Wydawnictwo Akademickie Żak.

Klus-Stańska, D. (2012). Konstruowanie wiedzy w szkole [Construction Knowledge at School]. Olsztyn: Wydawnictwo Uniwersytetu Warmińsko-Mazurskiego.

Klus-Stańska, D. (2018). Paradygmaty dydaktyki. Myśleć teoria o praktyce [Didactics Paradigms. Thinking about Practice by Theory]. Kraków: Wydawnictwo Naukowe PWN.

Kozielecki, J. (1995). Koncepcje psychologiczne człowieka [Psychological Concepts of Man]. Warszawa: Wydawnictwo "Żak".

Kwaśnica, R. (1994). Wprowadzenie do myślenia o wspomaganiu nauczycieli $w$ rozwoju [An Introduction to Thinking about Supporting Teachers in Development]. Wrocław: Wrocławska Oficyna Wydawnicza.

Kwaśnica, R. (2006). Wprowadzenie do myślenia o nauczycielu [An Introduction to Thinking about Teacher]. In Z. Kwieciński \& B. Śliwerski (Eds.), Pedagogika. Podręcznik akademicki [Education. Academic Handbook] (Vol. 2). Warszawa: Wydawnictwo Naukowe PWN.

Kwiatkowska, H. (2008). Pedeutologia [Pedeutology]. Warszawa: Wydawnictwa Akademickie i Profesjonalne.

Ledzińska, M., \& Czerniawska, E. (2011). Psychologia nauczania. Ujęcie poznawcze [Teaching Psychology. Cognitive Approach]. Warszawa: Wydawnictwo Naukowe PWN.

Lindblom-Ylänne, S., \& Lonka, K. (2000). Dissonant Study Orchestrations of High-Achieving University Students. European Journal of Psychology of Education, 15(1), 19. https:// doi.org/10.1007/BF03173164

Łukaszewski, W., \& Doliński, D. (2000). Mechanizmy leżące u podstaw motywacji [Mechanisms Underlying Motivation]. In J. Strelau (Ed.), Psychologia. Podręcznik akademicki [Psychology. Academic Handbook] (Vol. 2, pp. 441-468). Gdańsk: Gdańskie Wydawnictwo Psychologiczne.

Malewski, M. (2010). Od nauczania do uczenia się. O paradygmatycznej zmianie $w$ andragogice [From Teaching to Learning. About a Paradigmatic Change in Andragogy]. Wrocław: Wydawnictwo Naukowe Dolnośląskiej Szkoły Wyższej.

Michalak, R. (2004). Konstruktywistyczny model nauczania w edukacji elementarnej [Constructivist teaching model in elementary education]. In H. Sowińska \& R. Michalak (Eds.), Edukacja elementarna jako strategia zmian rozwojowych dziecka [Elementary Education as a Strategy of Child Developmental Changes] (pp. 183-191). Kraków: Oficyna Wydawnicza "Impuls".

Morton, A. (2009). Lecturing to Large Groups. In H. Fry, S. Ketteridge \& S. Marshall (Eds.), A Handbook for Teaching and Learning in Higher Education: Enhancing Academic Practice (pp. 58-71). New York, London: Taylor \& Francis.

Pritchard, A. (2009). Ways of Learning: Learning Theories and Learning Styles in the Classroom. London, New York: Routledge Taylor \& Francis Group.

Prosser, M., \& Trigwell, K. (1999). Understanding Learning And Teaching: The Experience in Higher Education: Society for Research into Higher Education \& Open University Press.

Ramsden, P. (2002). Learning to Teach in Higher Education. London and New York: Taylor \& Francis. 
Rutkowiak, J. (2009). Wielość paradygmatów dydaktyki a wspólny mianownik realności życia. Ku pytaniom o przekłady międzyparadygmatyczne [The Multitude of Didactics Paradigms and the Common Denominator of the Reality of Life. Towards Questions about Paradigmatic Translations]. In L. Hurło, D. Klus-Stańska \& M. Łojko (Eds.), Paradygmaty wspótczesnej dydaktyki [Paradigms of Modern Didactics] (pp. 27-49). Kraków: Oficyna Wydawnicza "Impuls".

Sajdak, A. (2013). Paradygmaty ksztatcenia studentów i wspierania rozwoju nauczycieli akademickich. Teoretyczne podstawy dydaktyki akademickiej [Paradigms of Educating Students and Supporting the Development of Academic Teachers. Theoretical Foundations of Teaching and Learning in Higher Education]. Kraków: OficynaWydawnicza "Impuls".

Sajdak-Burska, A. (2018). Hospitacje zajęć jako narzędzie wspomagania rozwoju nauczyciela akademickiego $\mathrm{w}$ roli dydaktyka [Class Observations as a Tool to Support the Development of an University Teacher as an Instructor]. In I. Maciejowska \& A. Sajdak-Burska (Eds.), Rozwijanie kompetencji dydaktycznych nauczycieli akademickich. Wybrane praktyki [Developing Teaching Skills of University Instructors. Selected Practices] (pp. 45-58). Kraków: Wydawnictwo Uniwersytetu Jagiellońskiego.

Samuelowicz, K., \& Bain, J. D. (2001). Revisiting Academics' Beliefs About Teaching and Learning. Higher Education, 41(3), 299-325. https://doi.org/10.1023/a:1004130031247

Schön, D. A. (1987). Educating the Reflective Practitioner: Toward a New Design for Teaching and Learning in the Professions. San Francisco: Jossey-Bass.

Smit, K., de Brabander, C., \& Martens, R. (2014). Student-Centred and Teacher-Centred Learning Environment in Pre-Vocational Secondary Education: Psychological Ne, and Motivation. Scandinavian Journal of Educational Research, 58(6), 695-712. https://doi.or $\mathrm{g} / 10.1080 / 00313831.2013 .821090$

Trigwell, K., Prosser, M., \& Waterhouse, F. (1999). Relations Between Teachers' Approaches to Teaching and Students' Approaches to Learning. Higher Education, 37(1), 57-70. https://doi.org/10.1023/A:1003548313194

Vermunt, J. D. (1995). Process-Oriented Instruction in Learning and Thinking Strategies. European Journal of Psychology of Education, 10(4), 325. https://doi.org/10.1007/ BF03172925

Wach, A. (2019). Stawanie się nauczycielem akademickim. W kierunku wspierania uczenia się poprzez refleksyjna praktykę [Becoming an Academic Teacher. Towards Supporting Learning through Reflective Practice]. Poznań: Wydawnictwo Kontekst.

Wright, G. B. (2011). Student-Centered Learning in Higher Education. International Journal of Teaching and Learning in Higher Education, 23(3), 92-97.

Wygotski, L. S. (1978). Narzędzie i znak $w$ rozwoju dziecka [Tool and Symbol in Child Development]. Warszawa: Wydawnictwo Naukowe: PWN.

Wynne, H. (1996). The Teaching of Science in Primary Schools. London: David Fulton Publishers Limited.

Yuen, K. M., \& Hau, K. T. (2006). Constructivist Teaching and Teacher Centred Teaching: A Comparison of Students' Learning in a University Course. Innovations in Education and Teaching International, 43(3), 279-290. https://doi.org/10.1080/14703290600750861 